\title{
Forage Yields and Plant Character Correlations in 30 Digitaria Selections
}

\author{
A. Sotomayor-Rios, J. Vélez-Fortuño, and G. Spain ${ }^{1}$
}

\section{INTRODUCTION}

Pangolagrass (Digitaria decumbens Stent) is well known to have contributed positively to the grassland agriculture of many tropical and subtropical countries of the world. Serious diseases and pests reported on Pangolagrass pastures $(3,4,5,6,9,21)^{2}$ justify expanding the introduction of Digitaria germ plasm for the purpose of intensifying our search for genotypes which could be used directly as forages or as superior parents in a breeding program. Fortunately, Digitaria germ plasm has been increased significantly in Florida, Puerto Rico and in many other countries of the Caribbean largely due to plant exploration in South Africa by A. J. Oakes in 1964 (7).

In Puerto Rico, Florida and other locations, detailed studies on the morphology, taxonomy and agronomy of these Digitarias have been conducted $(1,2, \$, 8,12,18,15,17,18,19)$; attempts likewise have been made to develop new techniques to produce superior forages through hydridization and selection with better agronomic characteristics than those found in Pangolagrass $(10,11,14,16,20)$.

The purpose of the present investigation was to evaluate: (a), 29 different entries of various Digitaria spp. in comparison with Pangolagrass for total yield and (b), a series of plant characters, during a period of one year at Rio Piedras, Puerto Rico. All possible correlations among yield and three independent variables were computed to study the possibility of utilizing these plant characters as a tool in the selection of superior types.

Correlation coefficients were determined for yield of green forage, dry matter and protein as dependent variables, and ground cover ability, resistance to rust, and resistance to yellow aphid infestation, as independent variables.

\section{MATERIALS AND METHODS}

Over 200 Digitaria accessions, most of them from the USDA collection (7), were space-planted in plots 3 feet by 3 feet. All the grasses were propagated vegetatively after having been released from quarantine.

1 Associate Plant Breeder in Charge, Corozal Substation, Head, Department of Plant Breeding and Associate Agronomist, Agricultural Experiment Station, Mayagüez Campus, University of Puerto Rico, Río Piedras, P. R.

2 Italic numbers in parentheses refer to Literature Cited, p. 61-2. 
The species distribution in this nursery was as follows: $D$. decumbens Stent, D. eriantha Steud., D. gazensis Rendle., D. longiflora (Retz) Pers., D. macroglossa Henr., D. milanjiana (Rendle) Stapf, D. milanjiana subsp. eylesiana Henr., D. pentzii Stent, D. polevansii Stent, $D$. setivalva Stent, $D$. smutsii Stent, $D$. swasilandensis Stent, $D$. valida Stent, and Digitaria sp. The original field identification of Oakes (7), was used.

All accessions were evaluated using visual ratings for the following plant characters: ground cover ability and/or vigor, growth type (bunch, decumbent, prostrate, etc.), reaction to the attack of rust (Puccinia oahuensis Ell and Ev.), and resistance to infestation by the yellow aphid (Sipha flava Forbes). The 29 best accessions and Pangolagrass are listed in table 1.

These Digitarias were planted on a Vega Alta clay loam, on January, 1966, using a randomized complete block design with four replications. A complete fertilizer, 14-4-10, was applied at a rate of 2,400 pounds per acre per year in six equal applications after each harvest at 60-day intervals. The plot size was 9 feet by 25 feet. A center swath, 42 inches by 25 feet, was weighed and samples from each plot were taken for dry matter and nitrogen determinations. The crude protein content was calculated using the factor 6.25 times $\mathrm{N}$ (nitrogen). Prior to each harvest at 60-day intervals, all plots were evaluated using visual ratings of one to nine, nine being the best condition. The plant characters rated were (a) ground cover ability and/or vigor, (b) resistance to rust, and (c) resistance to yellow aphid infestation.

\section{RESULTS AND DISCUSSION}

The green forage yields (table 2) ranged from 55,577 pounds per selection 16 to 124,764 pounds per acre per year for selection 5 . No significant differences were observed among selections $5,24,30,15,22,4,28$ and 14. Most of these grasses were significantly better than the remaining 22 Digitarias (5-percent level).

The three dependent variables were green forage $\left(Y_{1}\right)$, dry matter $\left(Y_{2}\right)$ and protein yield $\left(Y_{3}\right)$ per acre per year, respectively, while the independent variables were, ground cover ability and/or vigor $\left(X_{1}\right)$, resistance to the rust attack $\left(X_{2}\right)$ and resistance to yellow aphid infestation $\left(X_{3}\right)$.

All possible interrelationships among yield of green forage and the three independent variables are shown in table 3. Positive significant correlations, although low, were observed between total green forage and two of the independent variables, $Y_{1} X_{1}, r=0.34$ and $Y_{1} X_{3}, r=0.12$. A significant negative correlation was observed between total green forage and resistance to the rust attack, $Y_{1} X_{2}, r=-0.16$. The correlation coefficients among these variables for each of the six harvests are also shown in table 3. Positive significant correlations were observed between green forage and ground cover ability in all harvests except the second. The second lowest precipita- 
tion was observed during the period previous to the second harvest. In part, this could account for the low, nonsignificant correlation observed between green forage, dry matter and ground cover ability in that harvest

TABLE 1.-Thirly Digitarias selected from a space-planted nursery al Rfo Piedras, P.R., and their plant introduction (P.I. $)^{1}$ numbers

\begin{tabular}{|c|c|c|c|}
\hline \multirow{2}{*}{ Selection number } & \multirow{2}{*}{ Species field identifications } & \multicolumn{2}{|c|}{ Plant introduction number } \\
\hline & & USDA P.I. & P.R.P.I. \\
\hline 1 & D. milanjiana & 299655 & 6464 \\
\hline 2 & do. & 299695 & 6427 \\
\hline 3 & do. & 299696 & 6429 \\
\hline 4 & D. decumbens & - & 5125 \\
\hline 5 & D. milanjiana & 299699 & 6543 \\
\hline 6 & do. & 299667 & 6610 \\
\hline 7 & D. milaniiana subsp. eylesiana & 299716 & 6482 \\
\hline 8 & D. milanjiana & 299681 & 6494 \\
\hline 9 & D. milanjiana subsp. eylesiana & 299713 & 6613 \\
\hline 10 & do. & 299736 & 6658 \\
\hline 11 & do. & 299727 & 6628 \\
\hline 12 & do. & 299703 & 6378 \\
\hline 13 & do. & 299709 & 6391 \\
\hline 14 & do. & 299730 & 6415 \\
\hline 15 & do. & 299731 & 6416 \\
\hline 16 & D. setivalva & 299791 & 6471 \\
\hline 17 & do. & 299804 & 6537 \\
\hline 18 & D. smutsii & 299808 & 6373 \\
\hline 19 & do. & 299828 & 6434 \\
\hline 20 & D. milanjiana subsp. eyelesiana & 299728 & 6408 \\
\hline 21 & D. decumbens & 299601 & 6438 \\
\hline 22 & do. & 279651 & 5124 \\
\hline 23 & do. & 299837 & 6535 \\
\hline 24 & D. eriantha & - & 5277 \\
\hline 25 & D. valida & 299875 & 6433 \\
\hline 26 & D. pentzii & 299742 & 6405 \\
\hline 27 & do. & 299752 & 6439 \\
\hline 28 & D. setivalva & 299892 & 6402 \\
\hline 29 & D. decumbens & 296210 & 6523 \\
\hline 30 & do. & 111110 & - \\
\hline
\end{tabular}

1 U.S. Department of Agriculture and Agricultural Experiment Station, University of Puerto Rico, plant introduction numbers.

(tables 3,4 ). The highest negative correlations between green forage and rust resistance were obtained during the fourth and fifth harvests which were made during the last part of November 1966 and January 1967, respectively.

During the period of April 1966 to March 1967 a total of 71.71 inches of 
TABLE 2.-Comparison for the tolal green forage, dry matter and protein yields of $\$ 0$ Digitarias

\begin{tabular}{|c|c|c|c|c|c|}
\hline Selection & Green forage & Selection & Dry malter & Selection & Proteins yields \\
\hline Number & Lbs./acre/year & Number & Lbs./acre/year & Number & Lbs./acre/year ${ }^{2}$ \\
\hline 5 & 124,764 a & 24 & 40,484 a & 24 & 2,449 a \\
\hline 24 & 122,832 a b & 23 & 32,444 b & 5 & 2,255 a b \\
\hline 30 & 114,277 a c & 30 & 31,657 b c & 29 & 2,081 a c \\
\hline 15 & 113,792 a $c$ & 22 & 31,597 b c & 28 & 2,071 a c \\
\hline 22 & 113,513 a $\mathrm{c}$ & 4 & 31,522 b c & 19 & 2,031 a c \\
\hline 4 & 110,711 a $c$ & 5 & 30,676 b d & 23 & 2,016 a $c$ \\
\hline 28 & 108,321 a d & 21 & 30,263 b e & 11,22 & 1,956 a d \\
\hline 14 & 108,114 a d & 19 & 29,307 b e & 30 & 1,897 a e \\
\hline 21 & $101,343 \mathrm{~b}$ e & 27 & 28,212 b f & 4 & $1,857 \mathrm{~b} e$ \\
\hline 20 & $100,704 \mathrm{~b} e$ & 14 & $27,674 \mathrm{~b} g$ & 15 & $1,847 \mathrm{~b} e$ \\
\hline 23 & 97,394 c f & 11 & $26,868 \mathrm{~b} g$ & 21 & 1,767 b f \\
\hline 26 & 96,911 c $f$ & 15 & $26,594 \mathrm{~b} g$ & 27,14 & 1,757 b f \\
\hline 19 & $95,965 \subset \mathrm{g}$ & 2 & $26,455 \mathrm{~b} g$ & 20 & 1,752 b f \\
\hline 29 & 95,840 c $\mathrm{g}$ & 28 & $25,907 \mathrm{~b} \mathrm{~h}$ & 7,6 & $1,688 \mathrm{~b} \mathrm{~g}$ \\
\hline 27 & $94,431 \subset \mathrm{g}$ & 29 & 25,832 b h & 18 & $1,643 \subset \mathrm{g}$ \\
\hline 7 & $93,177 \subset \mathrm{g}$ & 20 & 24,961 c i & 12 & 1,553 c $\mathrm{g}$ \\
\hline 11 & 91,634 c h & 6 & 24,702 c i & 26 & 1,513 c $\mathrm{g}$ \\
\hline 6 & 87,801 d i & 26 & 24,379 с j & 2 & $1,508 \subset \mathrm{g}$ \\
\hline 18 & $87,367 \mathrm{~d} \mathbf{j}$ & 18 & $23,931 \mathrm{~d} j$ & 17 & 1,488 c $\mathrm{g}$ \\
\hline 2 & $86,705 \mathrm{~d} j$ & 7 & $23,816 d j$ & 1 & 1,469 c $g$ \\
\hline 17 & 78,491 e $\mathrm{k}$ & 17 & 23,020 e $\mathbf{k}$ & 8 & $1,394 \mathrm{~d} g$ \\
\hline 8 & 76,137 f 1 & 12 & 21,700 i k & 3 & $1,384 \mathrm{~d} g$ \\
\hline 12 & 73,863 g 1 & 13 & 21,028 f $k$ & 10 & $1,359 \mathrm{~d} g$ \\
\hline 13 & 70,138 h 1 & 3 & 20,511 j $\mathbf{k}$ & 25 & 1,329 e $g$ \\
\hline 10 & 68,834 i l & 1 & $19,136 \mathbf{j} k$ & 9 & 1,205 f $\mathrm{g}$ \\
\hline 1 & 68,186 i 1 & 10 & 18,703 h k & 13 & 1,170 f $g$ \\
\hline 3 & 65,259 i 1 & 8 & $18,529 \mathrm{~h} \mathrm{k}$ & 16 & $1,090 \mathrm{~g}$ \\
\hline 25 & 64,851 j 1 & 9 & 17,957 i $k$ & & \\
\hline 9 & $63,666 \mathrm{k} 1$ & 25 & $17,026 \mathbf{j}$ k & & \\
\hline 16 & 55,5771 & 16 & $15,841 \mathrm{k}$ & & \\
\hline
\end{tabular}

1 Means followed by the same letter are not significantly different $(0.05$ level of probability) by Duncan's multiple range test.

precipitation fell at the Río Piedras Station. The amount of precipitation which occurred during each of the 60-day intervals between harvests of the experiment was as follows:

$$
\text { Intervals }
$$

April-May 1966

June-July 1966

August-September 1966

October-November 1966

December 1966-January 1967

February-March 1967

$\begin{array}{rc}\text { Inches } & \text { Haroest number } \\ 14.05 & 1 \\ 10.89 & 2 \\ 17.48 & 3 \\ 13.57 & 4 \\ 11.00 & 5 \\ 4.72 & 6\end{array}$


A significant, although small, positive correlation was found between total green forage (table 3) and resistance to the yellow aphid infestation. It was in the sixth harvest that the lowest precipitation was recorded. It also was at this time when the highest positive correlation was observed

TABLE 3.-Correlation coefficients between green forage yields, ground cover ability and/or vigor, resistance to rust atlack, and resistance to yellow aphid infestalion for 30 Digitarias

\begin{tabular}{cccc}
\hline Green forage & $\begin{array}{c}\text { Groand coper ability } \\
\text { and/or sigor }\left(X_{1}\right)\end{array}$ & $\begin{array}{c}\text { Resistance to rust } \\
\text { allsck }\left(X_{2}\right)\end{array}$ & $\begin{array}{c}\text { Resistance to yellow aphid } \\
\text { infestation }\left(X_{3}\right)\end{array}$ \\
\hline Yield/pounds/acre & & & \\
Total for year $\left(Y_{1}\right)$ & $0.34^{*}$ & $-0.16^{*}$ & $0.12^{*}$ \\
First harvest & $0.38^{*}$ & 0.16 & 0.06 \\
Second “ & 0.02 & -0.11 & 0.02 \\
Third “ & $0.18^{*}$ & -0.04 & 0.06 \\
Fourth “ & $0.32^{*}$ & $-0.27^{*}$ & 0.09 \\
Fifth “ & $0.46^{*}$ & $-0.22^{*}$ & 0.15 \\
Sixth “ & $0.38^{*}$ & -0.12 & $0.28^{*}$ \\
\hline
\end{tabular}

* Significant at the 5 percent level.

Df for total green forage/A/year $=716$.

Df for green forage, lbs./A/on each of the six harvests (60-day interval) $=116$.

TABLE 4.-Correlation coefficients between dry matter yield, ground cover ability and/or vigor, resistance to rust attack and resistance to yellow aphid infestation for $\$ 0$

Digitarias

\begin{tabular}{lccc}
\hline Dry maller & $\begin{array}{c}\text { Ground coper ability } \\
\text { and/or vigor }\left(X_{1}\right)\end{array}$ & $\begin{array}{c}\text { Resistance to rast } \\
\text { allack }\left(X_{2}\right)\end{array}$ & $\begin{array}{c}\text { Resislance lo yellow } \\
\text { aphidi infestation }\left(X_{3}\right)\end{array}$ \\
\hline Yield/pounds/acre & & & \\
Total for year $\left(Y_{2}\right)$ & $0.29^{*}$ & $-0.12^{*}$ & $0.10^{*}$ \\
First harvest & $0.24^{*}$ & 0.09 & -0.01 \\
Second “ & 0.03 & -0.02 & 0.04 \\
Third “ & 0.16 & -0.01 & 0.07 \\
Fourth “ & $0.40^{*}$ & $-0.29^{*}$ & $0.20^{*}$ \\
Fifth “ & $0.41^{*}$ & $-0.18^{*}$ & 0.13 \\
Sixth “ & $0.33^{*}$ & -0.06 & $0.23^{*}$ \\
\hline
\end{tabular}

* Significant at the 5 percent level.

1)f for total dry matter/acre/year $=716$.

Df for dry matter, lbs/A on each of the six harvest (60-day interval) $=116$.

between green forage and resistance to infestation by the yellow aphid $(r=0.28)$. Apparently, the Digitarias exhibiting less yellow aphid infestation and, hence, more resistance to this insect attack, produce the highest yields, especially during cool dry periods at Río Piedras.

It would appear then that in the breeding and selection of Digitarias, in addition to other characters associated with yield, top priority should be 


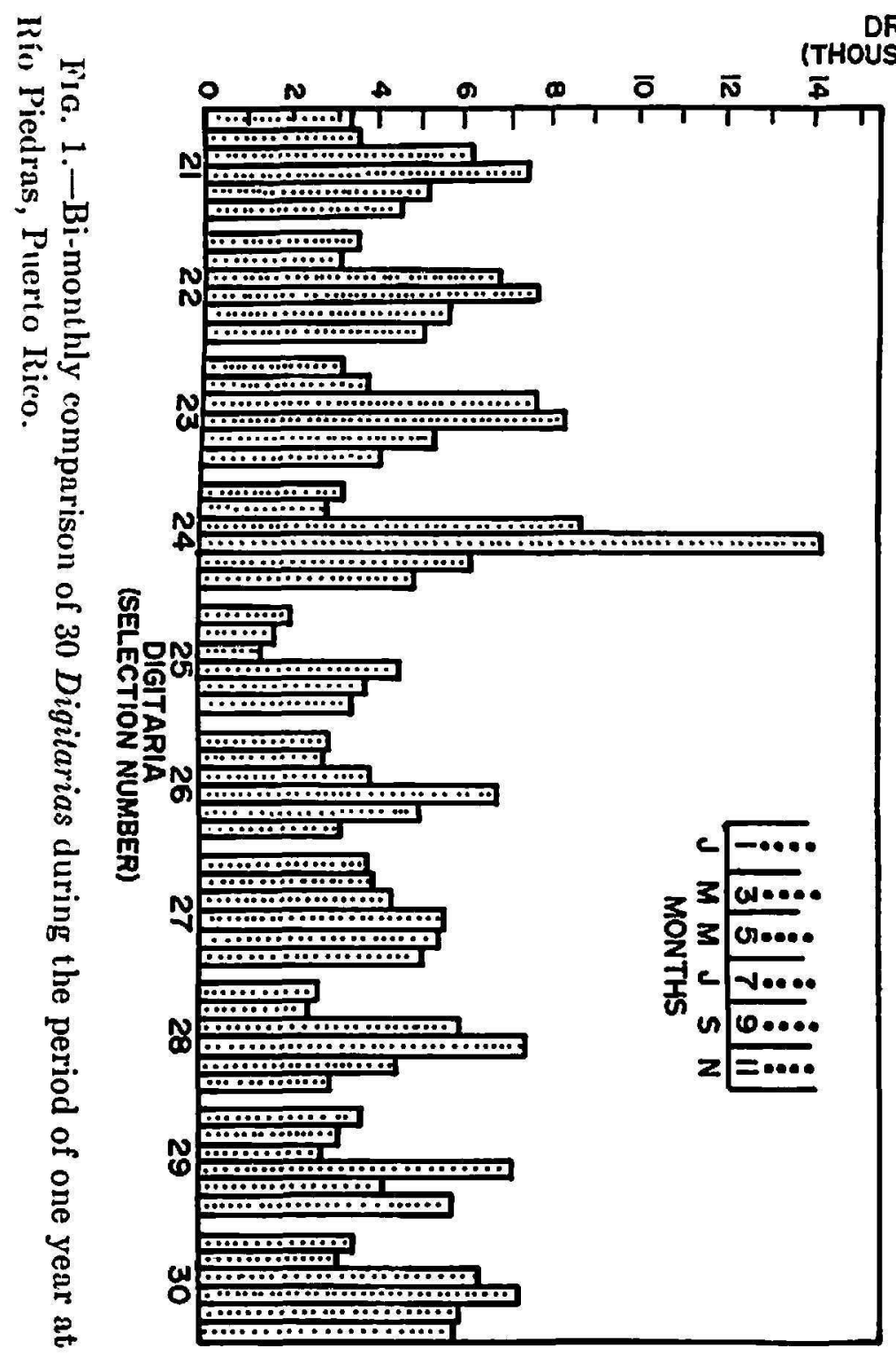

DRY MATTER YIELD

THOUSAND POUNDS PER ACRE)
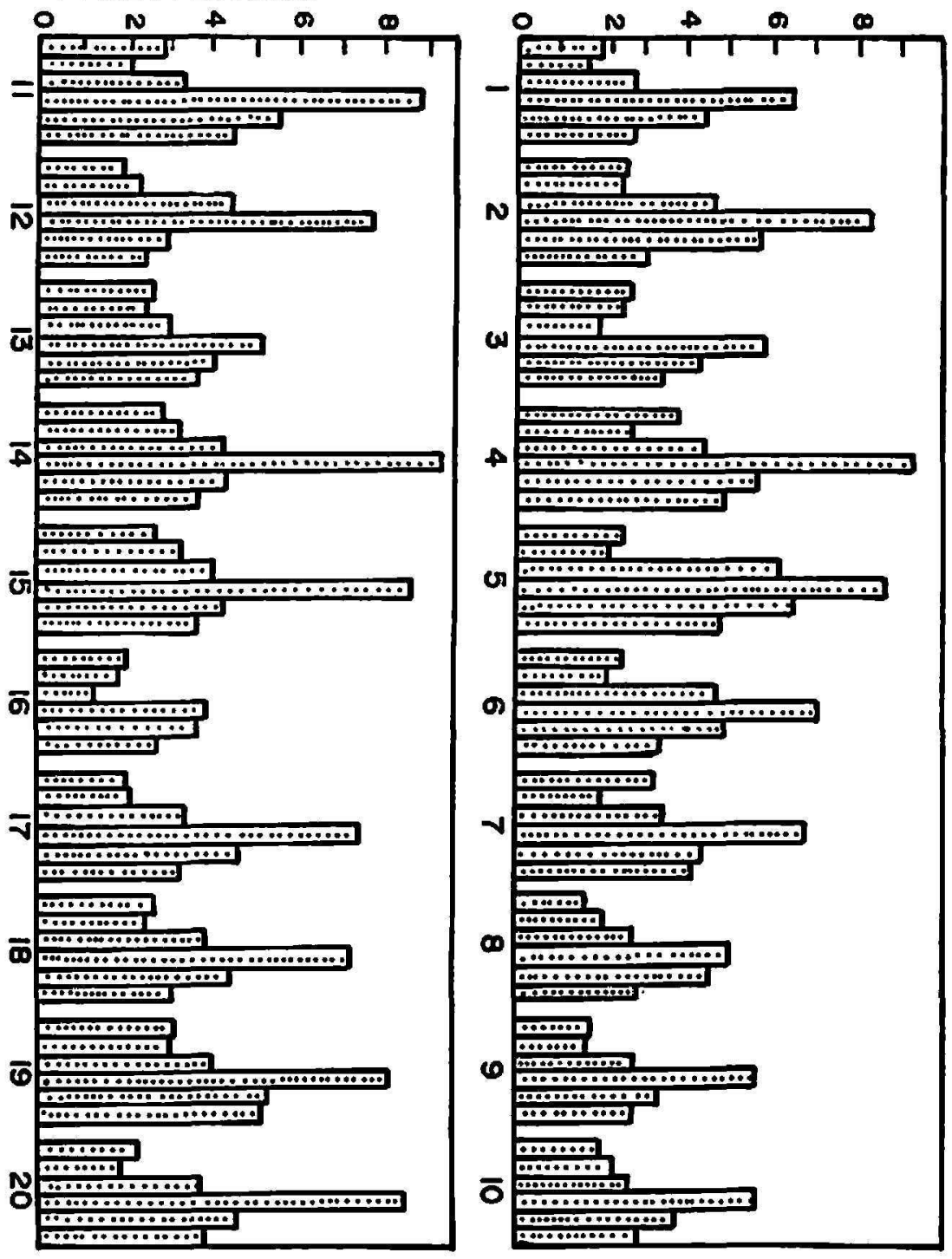

员 
given to plants showing less degree of yellow aphid infestation. This may result in the selection of plants offering higher resistance to yellow aphid attack. Resistance to rust, on the other hand, may be of less importance.

The data in table 2 and figure 1 show the total dry matter yields and the bi-monthly comparison for each of the 30 Digitarias. It can be seen clearly that the yields of all grasses were at their maximum during the July harvest at which selection $24, D$. eriantha, produced 40,484 pounds of dry matter, the highest yield. This selection proved significantly better than any of the other Digitarias tested, including Pangolagrass.

The correlation coefficients between the dry matter yields and the three independent variables of these 30 Digitarias are shown in table 4. The

TABLE 5.-Correlation coeficients between protein yield, ground cover ability and/or vigor, resislance to rust allack and resistance to yellow aphid infeslation for 30

Digitarias

\begin{tabular}{lccc}
\hline Protein yields & $\begin{array}{c}\text { Ground cover ability } \\
\text { and/or vigor }\left(X_{1}\right)\end{array}$ & $\begin{array}{c}\text { Resislance lo rust } \\
\text { allack }\left(X_{2}\right)\end{array}$ & $\begin{array}{c}\text { Resisance lo yellow aphid } \\
\text { infestation }\left(X_{3}\right)\end{array}$ \\
\hline Yield/pounds/acre & & & \\
Total for year $\left(Y_{3}\right)$ & $0.25^{*}$ & $-0.14^{*}$ & 0.03 \\
First harvest & $0.25^{*}$ & -0.07 & -0.02 \\
Sedond “" & -0.01 & -0.11 & -0.10 \\
Third " & 0.06 & -0.04 & 0.01 \\
Fourth " & $0.20^{*}$ & $-0.20^{*}$ & 0.05 \\
Fifth "6 & $0.26^{*}$ & -0.01 & 0.05 \\
Sixth " & $0.26^{*}$ & 0.00 & $0.17^{*}$ \\
\hline
\end{tabular}

* Significant at the 5 percent level.

Df for total protein lbs/A/year $=716$.

Df for protein, lbs/A on each of the six harvests (60-day interval) $=116$.

partial correlations between the dependent variable $(Y)$ and the independent variables $(X)$ followed a pattern similar to that shown in table 3.

Selection $24, D$. erianth a, ranked highest for total crude protein (table 2). However, no significant difference $(P=.05)$ was observed among the top eight Digitarias; their yields ranged from 1,897 to 2,449 pounds of crude protein per acre per year. The correlation coefficients between protein yields and the three independent variables are shown in table 5. The correlation coefficient between total protein (pounds per acre) and ground cover ability and/or vigor, $Y_{3} X_{1}(r=0.25)$, is significant at the 5-percent level. The correlation coefficient between total protein yield and rust resistance, is negative, as in the previous case, and significant at the 5-percent level.

Utilizing the same Digitarias and the same field experiment reported in this paper, Liu (5) concluded that the causal agent of the disease observed 
on these Digitarias, and on Pangolagrass, is a variant of Puccinia oahuensis. He tentatively identified it as $P$. oahuensis var. digitaria decumbensis and concluded that Digitaria clones P.I. 6438 and 6535 exhibited a high degree of resistance to Pangola rust.

It may be concluded that rust resistance may not be as important in a breeding program for the development of new Digitaria varieties as groundcover ability and/or vigor and resistance to infestation by the yellow aphid.

\section{SUMMARY}

The total green forage, dry matter, and protein yields per acre were determined for 30 Digitarias at the Río Piedras Experiment Station for a period of one year.

All grasses were harvested at 60-day intervals; prior to each cutting all plots were evaluated using visual ratings of one to nine, nine being the best condition. The following plant characters: ground cover ability and/or vigor $\left(X_{1}\right)$; resistance to the attack of rust caused by Puccinia oahuensis Ell. and Ev. $\left(X_{2}\right)$; and resistance to yellow aphid infestation Sipha flava Forbes $\left(X_{3}\right)$, were correlated with total green forage $\left(Y_{1}\right)$, total dry matter $\left(Y_{2}\right)$ and total pounds protein $\left(Y_{3}\right)$.

Significant positive correlations were obtained for $Y_{1} X_{1}(r=0.34)$, $Y_{1} X_{3}(r=0.12), Y_{2} X_{1}(r=0.29), Y_{2} X_{3}(r=0.10)$ and $Y_{3} X_{1}(r=0.25)$. Significant negative correlations were obtained between total green forage and resistance to rust attack, $Y_{1} X_{2}(r=-0.16)$; total dry matter yield and resistance to rust attack, $Y_{2} X_{2}(r=-0.12)$; and total protein yield and resistance to rust attack $Y_{3} X_{2}(v=-0.14)$. When the grasses were rated after each 60-day interval, the more vigorous grasses also were the most susceptible to the rust disease. None of the Digitarias exhibited complete resistance to either rust or to yellow aphid attack. The findings show that rust resistance is not as important in a Digitaria breeding program as ground cover ability and/or vigor and resistance to yellow aphid infestation.

Dry matter yields ranged from 15,841 to 40,484 pounds per acre yearly. One selection, D. eriantha (P.R.P.I. 5277), produced greater yields than the other Digitarias at the 5-percent level, including Pangolagrass.

\section{RESUMEN}

En la Estación Experimental Agrícola de Río Piedras se determinó el peso verde, peso seco y proteína total por acre de 30 Digitarias durante un año.

Todas las yerbas se cosecharon cada 60 días. Antes de cada corte, se evaluaron visualmente todas las parcelas usando una escala de uno al nueve, siendo el nueve la mejor condición. Los siguientes caracteres: 
habilidad para cubrir el terreno y/o vigor $\left(X_{1}\right)$; resistencia al ataque de la roya causado por el hongo Puccinia oahuensis Ell. and Ev. $\left(X_{2}\right)$; y resistencia a la infestación del áfido amarillo, Sipha flava Forbes $\left(X_{3}\right)$, se correlacionaron con el peso verde $\left(Y_{1}\right)$, peso seco $\left(Y_{2}\right)$ y libras de proteína total $\left(Y_{3}\right)$.

Se obtuvieron correlaciones positivas, significativas para $Y_{1} X_{1}(r=$ $0.34) ; Y_{1} X_{3}(r=0.12) ; Y_{2} X_{1}(r=0.29) ; Y_{2} X_{3}(r=0.10)$ y $Y_{3} X_{1}(r=$ 0.25). Se obtuvieron correlaciones negativas, significativas para el peso verde total y resistencia al ataque de la roya, $Y_{1} X_{2}(r=-0.16)$; el peso seco total y la resistencia al ataque de la roya, $Y_{2} X_{2}(r=-0.12)$; y la producción de proteína y resistencia al ataque de la roya, $Y_{3} X_{2}(r=$ -0.14). Cuando se llevó a cabo la evaluación de las yerbas, las más vigorosas también demostraron una tendencia a ser las más susceptibles al ataque de la roya. Ninguna de las Digitarias estudiadas demostraron una resistencia total al ataque de la roya o del áfido amarillo.

Se encontró que la resistencia a la roya no es tan importante en un programa de cruzamiento de la Digitarias como la habilidad de las yerbas para cubrir el terreno o su vigor de crecimiento, y resistencia a la infestación del áfido amarillo.

La producción de materia seca fluctuó entre 15,841 y 40,484 libras por acre por año. Una selección, D. eriantha (P.R.P.I. 5277), superó estadísticamente al 5 por ciento de probabilidad a las demás Digitarias, incluyendo la yerba Pangola.

\section{LITERATURE CITED}

1. Baskin, J. W., Schank, S. C., and West, S. H., Studies on germination and dormancy of Digitaria milanjiana (Rendle) Stapf, from tropical Africa, Soil Crop Sci. Proc. 27: 90-96, 1967.

2. Degras, L., Introduction ét étude de varietés de Digitaria aux Antilles, Ann. Amelior. Planles 18: 159-69, 1968.

3. Dirven, J. G. P. and Van Hoof, H. A., A destructive disease of Pangolagrass, Tijdschr. Plaiekt $66: 344-49,1960$.

4. Hodges, E. M., Killinger, G. B., McCaleb, J. E., Ruelke, O. C., Allen, R. J., Jr., Schank, S. C., and Kretschmer, A. E., Jr., Pangolagrass, Agr. Expt. Sta. Univ. Fla. Bull. 718. 31 pp., 1967.

5. Liu, L. J., Occurrence of Rust of Pangolagrass in Puerto Rico, J. Agri. Univ. P.R. 53: 132-39, 1969.

6. Nestel, B. L. and Creek, M. J., Pangolagrass, Herb. Abst. $82:$ 1-7, 1962.

7. Oakes, A. J., Digitaria collection in South Africa, Trop. Agr. 48: 323-31, 1965.

8. Oakes, A. J. and Langford, W. R., Cold tolerance in Digitaria, Agron. J. 59: 387-88, 1967.

9. Rodríguez, J. P., Rivera-Brenes, I., "El Cultivo de la Yerba Pangola en Puerto Rico", Est. Exp. Agr. Univ. P.R., Bull. 161, Febrero, 1962.

10. Schank, S. C., Improving pangolagrass, Sunshine Stale Agr. Res. Repl. 8: 14-15, 1963.

11. Schank, S. C. and Tan, N. V., Improvement of forage grasses by interspecific 
hybridization within the genus Digilaria, Proc. 61st Ann. Conv. Assoc. South. Agr. Workers 62: 63 p., 1964.

12. Schank, S. C. and Decker, H. F., The Florida Garden of Digitaria introductions, Sunshine State Agr. Res. Rept. 10: 8-9, April, 1965.

13. Schank, S. C., Decker, H. F., Killinger, G. B., and Allen, R. J., Jr., Agronomic and cytotaxonomic comparisons between Digitaria decumbens and $D$. pentzii, Crop Sci. 6: 82-3, 1966.

14. Schank, S. C., Duell, R. W., Steenmeijer, H. P., and Decker, H. F., Científicos buscan progenitores de la pangola para superar esterilidad, La Hacienda 62: 66-7, June, 1967.

15. Schank, S. C. and Decker, H. F., Cytological investigations in the genus Digitaria, Soil Crop. Sci. Proc. Fla. 27: 96-101, 1967.

16. Schank, S. C., Breeding grasses for resistance to pangolagrass stunt virus, Sunshine State Agr. Res. Rept. 13: 5-7, 1968.

17. Schank, S. C. and Edwardson, J. R., Cytological examination of pangolagrass (Digitaria decumbens Stent) infected with stunt virus, Crop Sci. 8: 118-19, 1968.

18. Shambulingappa, K. G., Studies on pachytene chromosomes in the genus Digitaria, Genetica $38:$ 381-87, 1968.

19. Shambulingappa, K. G., Cytomorphological and Sterility Studies in Digitaria polevansii, Stent. J. Agr. Univ. P.R. 53: 106-12, 1969.

20. Vega-Luna, M., Schank, S. C., and Ruelke, O. C., Seed-set temperature relationships as measured in a Digitaria milanjiana cross, Soil Crop Sci. Proc. Fla. 27: 101-06, 1967.

21. Wilson, P. N., Fewkes, D. W., and Emsley, M. G., Note on a Heavy Infestation of Pangolagrass (Digitaria decumbens Stent) by the Sugarcane Froghopper (Aeneolamia varia saccharina Distant), Trop. Agr. 39: 49-51, 1962. 